\title{
STUDY MATERIALS OF LICHENBIOTA OF CENTRAL PART OF THE LANDSCAPE PARK "PODLASIE BUG WATER GAP"
}

\author{
AnNa Matwiejuk \\ A. Matwiejuk, Institute of Biology, University of Białystok, Świerkowa 20 B, 15-950 Białystok, Poland, \\ e-mail: matwiej@uwb.edu.pl \\ (Received: October 9, 2013. Accepted: November 12, 2013)

\begin{abstract}
The paper presents a list of 94 species of lichens found in central part of the Landscape Park "Podlasie Bug Water Gap". Among them, 16 species are endangered in Poland. The most valuable components biota of lichen belong to endangered species nationally. They are: Melanelixia subargentifera, Pleurosticta acetabulum, Ramalina fraxinea, Usnea filipendula and others.
\end{abstract}

KEY WORDS: lichens, distributions, Podlasie Bug Water Gap, Landscape Park

\section{INTRODUCTION}

From the environmental point of view, one of the most interesting sections of the valley of the river Bug (which is a right tributary of the Vistula) is Podlasie Bug Water Gap, located on Polish territory and in a small part within the borders of Belarus. In 1993, the western part of the region became part of the Nadbużański Landscape Park formed on the left bank of the Bug, and in 1994 in the eastern part of the region, also on the left bank of the Bug, the "Podlasie Bug Water Gap" Landscape Park was established.

The modern vegetation of the Landscape Park "Podlasie Bug Water Gap" constitutes a mosaic of natural, semi-natural and man-made elements. Within the River Bug channel and its low flood terraces the original items of primary zonations of phytocoenoses have still preserved (SокоŁOWSKI 1991). This is favoured by the natural character of this part of the valley of the Bug, the diversity of plant design is maintained here due to spontaneous river overflows, also currently shaping geomorphological, humidity and soil conditions (WIERZBA et al. 2010). In the vicinity of the Bug there can be found coastal sandbars and sand dunes, xerothermal grasslands, hay meadows, and the entire spectrum of forest areas, including alder riparian, wetland, as well as wetland and aquatic communities. In the Podlasie Bug Water Gap there have been found so far about
160 syntaxa in the rank of association or community. The consequence of phytocoenotic diversification is a significant amount of floristic vascular plants, covering about 1050 species (ĆWIKLIŃsKI \& GŁOWACKI 2000, MarciniUK 2009).

In the Podlasie Bug Water Gap research has been conducted on plant communities of crop fields (RzYMOWSKA \& SKRZYCZYŃSKA 2006 a, b, c), communities of root crops (RzymowsKa 2010), fallow land flora (SKRZYCZYŃSKA \& Stachowicz 2007) and natural and semi-natural vegetation elements (Wierzba et al. 2010).

The biota of lichens of the Landscape Park "Podlasie Bug Water Gap" has not been developed so far, and in the available lichenological literature there are no reports of lichens of the area. Therefore, this work provides the first, valuable information about the current lichenbiota of the Park, from its central part.

\section{STUDY AREA}

"Podlasie Bug Water Gap" Landscape Park was created on the basis of the regulation of Biała Podlaska Governor of 25 August 1994, is located in the northern part of the Bialski county, on the territory of municipalities: Konstantynów, Janów Podlaski, Rokitno, Zalesie and Terespol, as well as in the two municipalities of the Łosice county: Platerów and Sarnaki. In physico-geographical terms, it consists 
of three geomorphologically varied parts, the mesoregions: Podlasie Bug Water Gap, flat Łukowska Plain and moraine Siedlce Plateau (outside Bialski county) (KONDRACKI 1998).

The main objective of the creation of the park was the preservation and protection of the natural state of the most valuable parts of the left-bank valley of the Bug in terms of nature, landscape and culture oxbow lakes, river meanders and forests.

The length of the park in a straight line is $65 \mathrm{~km}$, the average width of the western part, lying within limits of the Masovian voivodeship is $6 \mathrm{~km}$, of the eastern part, located in the Lublin Voivodeship and bordering Belarus, $3-5 \mathrm{~km}$. The Park covers an area of 30.904 ha and 17.131 ha of buffer zone. Forests cover $33.4 \%$ of the park area, meadows and pastures $21.6 \%$, surface waters $2.6 \%$, and the remaining area comprises arable land and technical infrastructure (Marciniuk 2009, Przyroda... http://www.podlaskiprzelombugu.pl/przyroda.html).

On the territory of the Landscape Park "Podlasie Bug Water Gap" there were found 765 species of vascular plants, including 18 species of spore plants, five species of gymnosperms and 742 species of angiosperm plants. There are 34 species of trees, 50 species of shrubs and undershrubs and 681 species of herbaceous plants. Of the protected plants, 36 species are under strict protection and 16 are partially protected (ĆWIKLIŃSKI \& GŁOWACKI 2000).

\section{MATERIAL AND METHODS}

Field studies were carried out in 2011-2012, at 12 sites, located in the central part of the Park (Fig. $1)$. In laboratory works, methods of morphological-anatomical and chemotaxonomical analysis were applied (Orange et al. 2001). The alphabetical list of lichen species has been compiled. Analysis of secondary metabolites of lichens were made for the following taxa: Cladonia chlorophaea, C. merochlorophaea, C. novochlorophaea, C. fimbriata, C. glauca, C. pyxidata, C. rei, Lecanora expallens, Lepraria elobata and L. incana. For the alphabetical list of lichen species, listed in the study area. For each taxon we have specified the type of substratum it can be found on and numbers of positions. The protected and endangered species are marked.

The species have been named according to FAETYNOWICZ (2003) and species Melanohalea exasperatula to Blanco et al. (2004), Caloplaca flavocitrina to ARUP (2006), Lecanora saxicola to LAUNDON (2010), Melanelixia glabratula to Arup \& SANDLER BerLin (2011).

\section{RESULTS}

In the study area 94 lichen species were recorded, including 49 epiphytic, 37 epigeic, 29 epixylic and nine epilithic species. Lichens are represented by 35 genera. The most abundant numbers of species represented here are those of genera Cladonia (30),

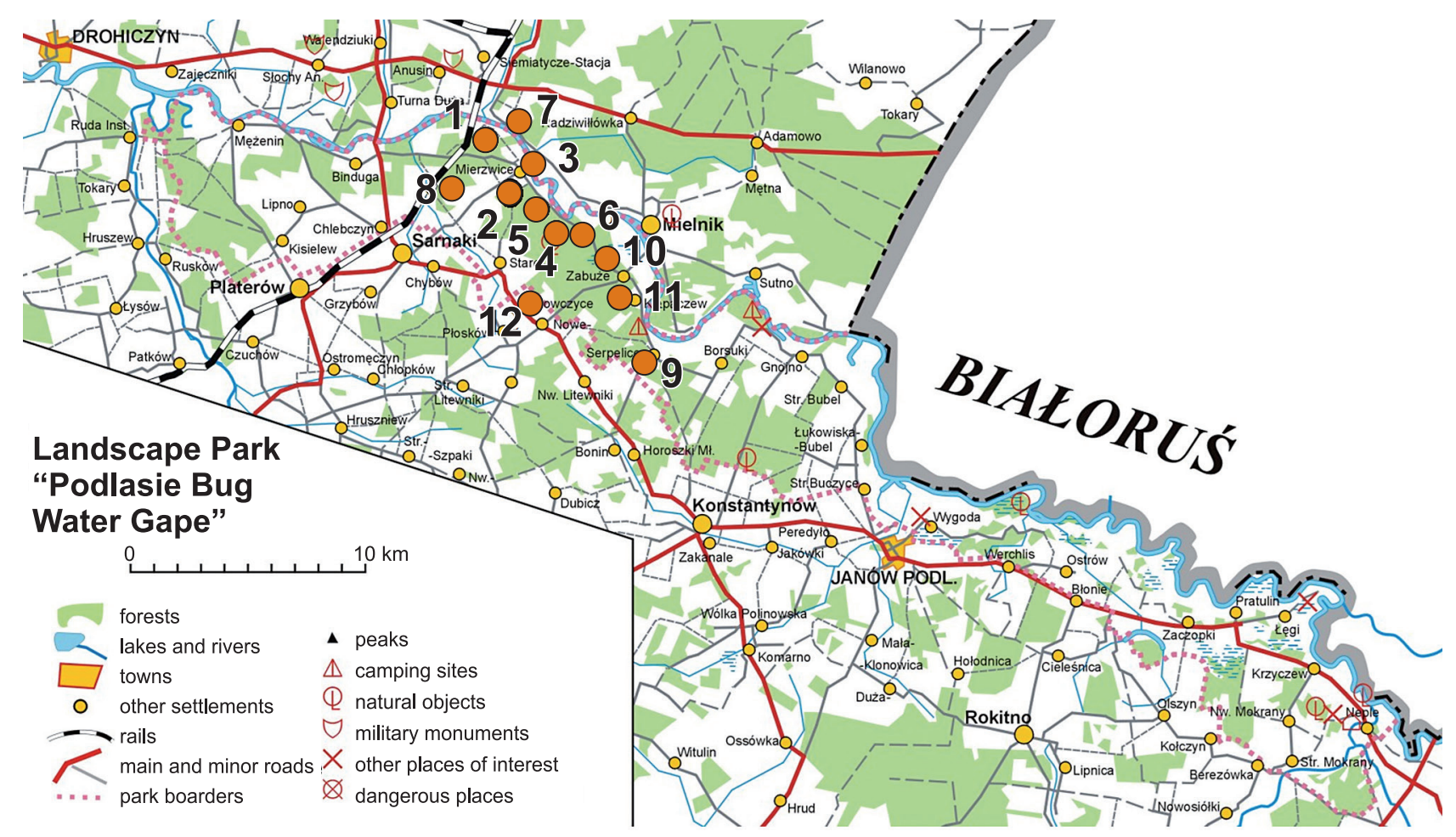

Fig. 1. Distribution of stands of central part of Landscape Park "Podlasie Bug Water Gap" (http://www.survival.strefa.pl/trn/md/przelom_bugu-mp.jpg) 
Lecanora (10), Cetraria and Physcia (such as 4). In lichenbiota the dominant lichens are multiform thalli of Cladonia (30 species) and small crustose lichens (29) and foliose lichens (23).

Stands:

1. Railway station Mierzwice Stare, lane along the railway embankment towards the Bug - Populus tremula;

2. Around Mierzwice, a group of trees Alnus glutinosa on the area of 2-3 acres in the backwater of stagnant water;

3. Around Mierzwice, a group of trees - Quercus robur, poplar Populus tremula, Pyrus communis in the meadow on floodplain terrace, $30 \mathrm{~m}$ from the river;

4. A group old Salix sp. on the banks of the river leaning towards the water, at wild fishing harbour and Quercus rubra, Tilia cordata;

5. A group of old Salix sp. growing in the backwater of the river over a distance of $50 \mathrm{~m}$, right-bank part of the Bug River valley in the vicinity of Maćkowice colony;

6. A group of trees Salix sp. and Populus tremula growing in a narrow strip between the river bed and the asphalt road from Siemiatycze to Mielnik;

7. A group of trees Salix sp. growing in the meadow, 400 meters from the village Osłowo;

8. Around Mierzwice, Forestry Mierzwice, pine forest Peucedano-Pinetum - the soil, Pinus sylvestris;

9. Surroundings of Serpelice, pine forest Peucedano-Pinetum - soil, Pinus sylvestris;

10. Surroundings of Zabużan, pine forest Peucedano-Pinetum - soil, Pinus sylvestris;

11. Surroundings of Klepaczewo, pine forest Peucedano-Pinetum - soil, Pinus sylvestris;

12. Stare Hołowczyce - Populus tremula, Salix sp., concrete and wooden structures.

\section{LIST OF SPECIES OF LICHENS}

Amandinea punctata (Hoffm.) Coppins \& Scheid. - on bark of Populus tremula, Pyrus communis, Salix sp.; stands: $1-7,12$

Caloplaca decipiens (Arnold) Blomb. \& Forss. - on concrete; stand: 12

Caloplaca flavocitrina (Nyl.) H. Olivier - on concrete; stand: 12

Candelaria concolor (Dicks.) Stein - on bark of Populus tremula, Quercus robur, Salix sp., Tilia cordata; stands: 1, 3-7

Candelariella aurella (Hoffm.) Zahlbr. - on concrete; stand: 12

Candelariella xanthostigma (Ach.) Lettau - on bark of Alnus glutinosa, Populus tremula, Quercus robur, Salix sp.; stands: 2-7, 12
Cetraria aculeata (Schreb.) Ach. - on soil; stand: 8; partially protected species

Cetraria chlorophylla (Willd.) Vain. - on bark of Tilia cordata; stand: 4, strictly protected species, VU

Cetraria ericetorum Opiz - on soil; stand: 8; partially protected species, NT

Cetraria islandica (L.) Ach. - on soil; stands: 8-10; partially protected species, VU

Cladonia arbuscula (Wallr.) Flot. em. Ruoss subsp. mitis - on soil; stands: 8-10; partially protected species

Cladonia arbuscula (Wallr.) Flot. em. Ruoss subsp. squarrosa (Wallr.) Ruoss - on soil; stands: 8-10; partially protected species

Cladonia cenotea (Ach.) Schaer. - on wood; stand: 8

Cladonia cervicornis (Ack.) Flot. - on soil; stand: 8

Cladonia chlorophaea (Flörke ex Sommerf.) Spreng. - on bark of Pinus sylvestris, Populus tremula, Salix sp., on soil, wood; stands: 4, 7-11

Cladonia cornuta (L.) Hoffm. - on soil, wood; stand: 8 Cladonia crispata (Ach.) Flot. - on soil; stand: 8

Cladonia cryptochlorophaea Asahina - on soil; stand: 8

Cladonia deformis (L.) Hoffm. - on soil, wood; stands: 8-11

Cladonia digitata (L.) Hoffm. - on soil, wood; stands: 8-11

Cladonia fimbriata (L.) Fr. - on soil, wood; stands: 8-11

Cladonia foliacea (Huds.) Willd. - on soil; stand: 8

Cladonia furcata (Huds.) Schrad. - on soil; stands: 8-11

Cladonia glauca Flörke - on soil, wood; stands: 8-10

Cladonia gracilis (L.) Willd.- on soil, wood; stand: 8

Cladonia grayi Merrill ex Sandst. - on soil, wood; stand: 8

Cladonia macilenta Hoffm. subsp. floerkeana (Fr.) Flörke - on soil, wood; stands: 8-10

Cladonia macilenta Hoffm. subsp. macilenta - on soil, wood; stands: 8, 10, 11

Cladonia merochlorophaea Asahina - on soil; stand: 8

Cladonia novochlorophaea (Sipman) Brodo \& Ahti - on soil; stand: 8

Cladonia ochrochlora Flörke - on soil, wood; stand: 8

Cladonia phyllophora Hoffm. - on soil; stands: 8-11

Cladonia portentosa (Dufour) Coem. - on soil, stand: 8; partially protected species

Cladonia pyxidata (L.) Hoffm. s.l. - on soil, wood; stands: 8,11

Cladonia ramulosa (With.) J.R. Laundon - on soil, wood; stand: 8

Cladonia rangiferina (L.) Weber in F.H. Wigg. - on soil; stands: $8-11$; partially protected species

Cladonia rei Schaer. - on soil, wood; stand: 8

Cladonia squamosa (Scop.) Hoffm. - on soil, wood; stand: 8

Cladonia subulata (L.) Weber in F.H. Wigg. - on soil, wood; stands: 8,10

Cladonia sulphurina (Michx.) Fr.- on soil; stand: 8, NT 
Cladonia uncialis (L.) F.H. Wigg. - on soil; stands: 8-10

Evernia prunastri (L.) Ach. - on bark of Populus tremula, Pyrus communis, Quercus robur, Salix sp.; stands: 3-7; partially protected species, NT

Hypocenomyce scalaris (Ach.) Choisy - on bark of $\mathrm{Al}$ nus glutinosa, Pinus sylvestris; stands: 8-11

Hypogymnia physodes (L.) Nyl. - on bark of Alnus glutinosa, Pinus sylvestris, Populus tremula, Pyrus communis, Quercus robur, Salix sp., on wood; stands: 1-12

Hypogymnia tubulosa (Schaer.) Hav. - on bark of Populus tremula, Quercus robur; stands: 1, 3, 4, 6; totally protected species, NT

Imshaugia aleurites (Ach.) S.L.F. Meyer - on bark of Pinus sylvestris, on wood; stands: 8 , 9; totally protected species

Lecania cyrtella (Ach.) Th. Fr. - on bark of Populus tremula, Salix sp.; stands: $3-6,8$

Lecania fuscella (Schaer.) A. Massal. - on bark of Populus tremula, Quercus robur, Salix sp., Tilia cordata; stands: 3, 4, 7; NT

Lecanora allophana (Ach.) Nyl. - on bark of Alnus glutinosa, Populus tremula, Salix sp.; stands: 2, 4-7

Lecanora carpinea (L.) Vain. - on bark of Populus tremula, Quercus robur, Salix sp., Tilia cordata; stands: $1-7,12$

Lecanora chlarotera Nyl. - on bark of Alnus glutinosa, Populus tremula, Tilia cordata; stands: 1, 2, 4

Lecanora conizaeoides Nyl. in Cromb. - on bark of Alnus glutinosa, Pinus sylvestris, Populus tremula, Pyrus communis, Quercus robur, Salix sp., Tilia cordata; stands: 1-11

Lecanora expallens Ach. - on bark of Populus tremula, Pyrus communis, Quercus robur; stands: 1, 3, 4

Lecanora hagenii (Ach.) Ach. - on bark of Populus tremula, Pyrus communis, Quercus robur, Salix sp.; stands: 3-6, 12

Lecanora pulicaris (Pers.) Ach. - on bark of Populus tremula; stands: 3,6

Lecanora saligna (Schrad.) Zahlbr. - on bark of Populus tremula; stands: 1, 3, 6

Lecanora saxicola (Pollich) Ach. - on concrete; stand: 12

Lecanora symmicta (Ach.) Ach. - on bark of Populus tremula; stands: 3,6

Lecidella elaeochroma (Ach.) M. Choisy - on bark of Populus tremula, Quercus robur, Salix sp., Tilia cordata; stands: 1, 3-7, 11

Lepraria elobata Tønsberg - on bark of Pinus sylvestris; stands: 8-10

Lepraria incana (L.) Ach. - on bark of Pinus sylvestris, Pyrus communis, Quercus robur, Salix sp., on wood; stands: $3-11$

Melanelixia glabratula (Lamy) Sandler \& Arup. - on bark of Populus tremula, Quercus robur, Salix sp., on wood; stands: $1-7,12$; totally protected species

Melanelixia subargentifera (Nyl.) O. Blanco, A. Crespo, Divakar, Essl., D. Hawksw. \& Lumbsch - on bark of Populus tremula; stand: 3; totally protected species, VU

Melanohalea exasperatula (Nyl.) O. Blanco, A. Crespo, Divakar, Essl., D. Hawksw. \& Lumbsch - on bark of Alnus glutinosa, Populus tremula, Pyrus communis, Quercus robur, Salix sp., Tilia cordata; stands: 2-7; totally protected species

Micarea denigrata (Fr.) Hedl. - on wood; stand: 8

Parmelia sulcata Taylor - on bark of Alnus glutinosa, Populus tremula, Pyrus communis, Quercus robur, Salix sp., Tilia cordata; stands: $1-8,12$

Parmeliopsis ambigua (Wulfen in Jacq.) Nyl. - on bark of Pinus sylvestris, on wood; stands: 8-10; totally protected species

Peltigera canina (L.) Willd. - on soil; stand: 8; totally protected species, VU

Peltigera didactyla (With.) J.R. Laundon - on soil; stand: 8; totally protected species

Peltigera rufescens (Weiss) Humb. - on soil; stand: 8; totally protected species

Pertusaria amara (Ach.) Nyl. - on bark of Alnus glutinosa, Quercus robur; stands: 2-4

Phaeophyscia orbicularis (Neck.) Moberg - on bark of Populus tremula, Pyrus communis, Quercus robur, Salix sp., on concrete; stands: 1, 3-7, 11

Phlyctis argena (Ach.) Flot. - on bark of Populus tremula, Quercus robur, Salix sp., Tilia cordata; stands: 3-7

Physcia adscendens (Fr.) H. Olivier - on bark of Populus tremula, Salix sp., on concrete; stands: 3-7, 12

Physcia dubia (Hoffm.) Lettau - on bark of Alnus glutinosa, Populus tremula, Pyrus communis, Quercus robur, Salix sp., Tilia cordata, on concrete; stands: $1-7,12$

Physcia stellaris (L.) Nyl. subsp. stellaris - on bark of Populus tremula, Pyrus communis, Quercus robur, Salix sp.; stands: 1, 3-6, 8, 12

Physcia tenella (Scop.) DC. in Lam. \& DC. - on bark of Populus tremula, Salix sp., Tilia cordata; stands: $3-7,12$

Physconia enteroxantha (Nyl.) Poelt - on bark of Salix sp., Tilia cordata; stands: 4-7, 12

Physconia grisea (Lam.) Poelt - on bark of Alnus glutinosa, Pyrus communis, Quercus robur, Salix sp., Tilia cordata; stands: $2-7$

Placynthiella uliginosa (Schrad.) Coppins \& P. James on soil, wood; stand: 8

Pleurosticta acetabulum (Neck.) Elix \& Lumbsch in Lumbsch, Kothe \& Elix - on bark of Quercus robur; stand: 4; totally protected species, EN

Pseudevernia furfuracea (L.) Zopf - on bark of Pinus sylvestris, Populus tremula, Quercus robur, Salix sp., on wood; stands: $3,4,7,9,10$; totally protected species

Ramalina farinacea (L.) Ach. - on bark of Alnus glutinosa, Populus tremula; stands: 2, 12; totally protected species, VU 
Ramalina fraxinea (L.) Ach. - on bark of Populus tremula, Quercus robur, Salix sp.; stands: 3-7, 12; totally protected species, EN

Ramalina pollinaria (Westr.) Ach. - on bark of Populus tremula, Salix sp.; stands: 4-7; totally protected species, EN

Rinodina pyrina (Ach.) Arnold - on bark of Alnus glutinosa, Populus tremula, Salix sp.; stands: 2, 4, 7

Scoliciosporum chlorococcum (Graeve ex Stenh.) Vězda - on bark of Pinus sylvestris, Populus tremula, Pyrus communis, Salix sp.; stands: $3-8,12$

Trapeliopsis granulosa (Hoffm.) Lumbsch - on soil, wood; stand: 8

Trapeliopsis viridescens (Schrad.) Coppins \& P. James na wood; stand: 8, NT

Usnea filipendula Stirt. - on bark of Populus tremula, Salix sp.; stands: 4-7; totally protected species, VU

Usnea hirta (L.) Weber ex F.H. Wigg. - on bark of Alnus glutinosa, Pinus sylvestris, Populus tremula, Salix sp.; stands: 2, 4, 7, 9; totally protected species, VU

Xanthoria parietina (L.) Th. Fr. - on bark of Alnus glutinosa, Populus tremula, Pyrus communis, Quercus robur, Salix sp., Tilia cordata, on concrete, wood; stands: $1-7,12$

Xanthoria polycarpa (Hoffm.) Rieber - on bark of $\mathrm{Al}$ nus glutinosa, Populus tremula, Pyrus communis, Quercus robur, Salix sp., on concrete; stands: 1-7, 12.

Of the 94 species of lichens recorded in the study area 49 were found on the bark of trees, 37 on soil, 30 on wood and nine on epilithic substrates.

Epiphythes. The most numerous group of lichens of the Landscape Park "Podlasie Bug Water Gap" are epiphytic species.

Most of the recorded species of lichens are very common in lowland Poland on trees growing in open areas, in fields, meadows, over rivers and along roads (Bystrek \& Kolanko 2000). The highest species diversity was observed on the bark of aspen Populus tremula - 39 species and willow Salix - 32 (Fig. 2).

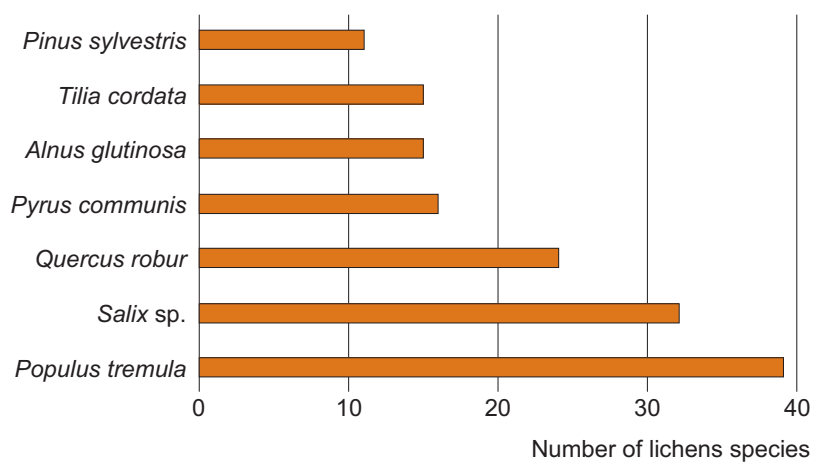

Fig. 2. Number of lichens species on selected phorophyte on the central part of Landscape Park "Podlasie Bug Water Gap"
The bark of these trees is abundant in thalli of Phaeophyscia orbicularis, Physcia adscendens, P. dubia. $P$. stellaris, P. tenella, Physconia grisea, P. enteroxantha, Candelariella xanthostigma, Xanthoria parietina, Melanohalea exasperatula. Crustose lichens of the genus Lecanora are also numerous.

Only on the bark of Populus tremula were found: Lecanora pulicaris, L. saligna, L. symmicta, on the bark of Tilia cordata: Cetraria chlorophylla, on the bark of Quercus robur: Pleurosticta acetabulum, and on the bark of Pinus sylvestris: Lepraria elobata.

The most common tree in the forests of the Park is pine Pinus sylvestris, which forms here multihectare pine forests Peucedano-Pinetum. Despite the vast quantitative dominance of pine, the number of species of lichens associated with its bark in the study area is relatively small. Only 11 species have been recorded here, most of which are common taxa in the country (CIEŚLIŃSKI 2003 a) and those tolerant of high acidity of the substrate (BARKMAN 1969), such as Cladonia coniocraea, Lecanora conizaeoides, Hypocenomyce scalaris, Scoliciosporum chlorococcum.

Epigeic lichens. Another large group occurring within the park are epigeic lichens (37 species). Species of the genus Cladonia dominate, most of which are common in the country. Epigeic lichens inhabit mostly well-lit and dry roadsides, edges of pine forests, sand dunes and in the depths of woods they often form dense, bright carpets, among which inconspicuous crustose thalli of Placynthiella uliginosa massively develop. Cetraria aculeata and C. islandica can be also encountered here.

Only on the soil grow 21 species, including: Cladonia arbuscula, C. cervicornis, C. foliacea, C. ramulosa, C. sulphurina, Peltigera canina, $P$. didactyla which are rare species in the study area.

Epixylous lichens. On the wood 29 species of lichens were recorded. Cladonia cenotea, Micarea denigrata and Trapeliopsis viridescens grow exclusively on rotten stumps. These substrates become also colonized by the species growing in the soil, such as Cladonia chlorophaea, C. cornuta, C. deformis, C. digitata, C. fimbriata, C. glauca, C. gracilis, C. grayi, C. macilenta, C. ochrochlora, C. pyxidata, C. ramulosa, C. rei, C. squamosa, C. subulata, Placynthiella uliginosa, Trapeliopsis granulosa as well as on the bark of trees Imshaugia aleurites, Lepraria incana, Parmeliopsis ambigua. Species showing preference for the bark of trees such as Hypogymnia physodes, Melanelixia glabratula, Pseudevernia furfuracea, Xanthoria parietina were recorded on wooden structures.

Epilithic lichens. The biota of epilithic lichens of the park is very poor and because of the absence of other substrates, it is limited to calcyphile species inhabiting artificial limestone substrates such as concrete columns, bridges, walls (CIEŚLIŃSKI 2008). All the species found here are common in the country (Bystrek \& Kolanko 2000). 


\section{PARTICIPATION OF VULNERABLE AND PROTECTED LICHENS}

Of the 94 lichen species identified in the Landscape Park "Podlasie Bug Water Gap" 16 species have been put on the Red list of extinct and vulnerable lichens of Poland (CiEśLiŃski et al. 2006), including the two species in the endangered category - EN (Pleurosticta acetabulum, Ramalina fraxinea), eight species in the vulnerable category - VU (Cetraria chlorophylla, C. islandica, Melanelixia subargentifera, Peltigera canina, Ramalina farinacea, R. pollinaria, Usnea hirta, $U$. filipendula) and six species in the category of near threatened - NT (Cetraria ericetorum, Cladonia sulphurina, Evernia prunastri, Hypogymnia tubulosa, Lecania fuscella, Trapeliopsis viridescens).

The most threatened ecological group in the reserve are epiphytes.

Of all the 94 lichen species of the reserve, 24 have been put under legal protection, 17 of which are totally, including two requiring the setting of the protection zones of refuge or posts and seven of which is partially protected (RozPoRZĄDZENIE... 2004).

\section{DISCUSSION}

The study allowed to determine the species composition of lichens in the middle part of the Landscape Park "Podlasie Bug Water Gap". The presence of 94 species of lichens was noted.

In the Masovian voivodeship and the Podlaskie voivodeship, which neighbours with it to the east, there are 12 landscape parks, including nine in the Masovian and three in the Podlaskie voivodeship. The lichenological study has so far been conducted only in: the Kozienicki Landscape Park (CIEśLIŃsKI 2003 b, 2007, 2008), Knyszyńska Forest Landscape Park (Bystrek \& Kolanko 2000) and Suwalski Landscape Park (ZALEWSKA et al. 2004). On the territory of the Kynyszyńska Forest LP 341 species of lichens have been identified (Bystrek \& Kolanko 2000). A characteristic feature of the lichenbiota of the Knyszyńska Forest is a large taxonomic, morphological and phytogeografical diversity of epiphytes. In the Suwalski LP 231 species of lichens have been recorded, including 123 species on the bark of trees and 102 species on rock substrate (ZaLEwSKA et al. 2004). The biota of lichens of the Kozienicka Forest has 233 species belonging to 76 genera, among which the richest is genus Cladonia represented by 29 species (CIEśLIŃSKI 2003 b). Species richness of lichens of the Knyszyńska Forest and Kozienicka Forest is related to the dominance of species which are natural components of forest biocenosis and that of the Suwalski Park is especially related to the unique epilithic lichenbiota colonizing boulders, among which mountain species are present, such as Rhi- zocarpon lecanorinum, Umbilicaria deusta, U. polyphylla (ZALEWSKA et al. 2004).

On the territory of the parks, in the epiphytic lichenbiota widespread lichens colonizing acidic pine bark dominate, reaching a high class attendance, e.g. Hypogymnia physodes, Lecanora conizaeoides, $\mathrm{Hy}$ pocenomyce scalaris and others. They usually grow abundantly and cover large areas of tree trunks. In the audited park in open areas (roadside trees, trees growing on river banks, trees in agricultural landscape) among epiphytes there dominate lichens associated with the bark of deciduous trees. These are common and widely distributed lichens. They include numerous species frequently found previously in the study area: Melanohalea exasperatula, Parmelia sulcata, Phaeophyscia orbicularis, Physcia adscendens, $P h$. tenella, Physconia grisea, Xanthoria parietina and X. polycarpa. Some of these species are nitrophilous and coniophylous lichens.

Among the lichens recorded in the Lanscape Park "Podlasie Bug Water Gap" the most numerous species are of genus Cladonia (30), growing on the soil in pine forests. The frequent presence of Cladonia in the study area is associated with the occurrence of suitable habitats. Sterile, loose, sandy soils favor the development of inland forests. Related species belonging to the above-mentioned type also occurred in the Kozienicka Forest (CIEŚLIŃSKI 2003 b, 2007, 2008). Worthy of note is the record of rare species such as Cladonia ramulosa and C. sulphurina growing in humus-rich soil in pine forests.

The presented research results of the Landscape Park "Podlasie Bug Water Gap" constitute a contribution to the knowledge of lichenbiota of the whole park. These results should be seen as a pilot study for future research. The results show the diversity of species, especially epigeic and epiphytic lichens of that area.

\section{CONCLUSION}

On the area of the Landscape Park "Podlasie Bug Water Gap" 94 species of lichens were found, including the vast majority, as high as $51 \%$ of epiphytic lichens. Rare species in the park are: Melanelixia subargentifera, Pleurosticta acetabulum, Ramalina farinacea, R. pollinaria, Usnea hirta, U. filipendula.

Richly represented in the Park are epigeic lichens. They colonize mainly well-lit and dry roadsides, edges of pine forests. Species of the genus Cladonia (30) dominate. Epilithic lichens are represented only by calciphilous species inhabiting artificial limestone substrates.

\section{ACKNOWLEDGEMENTS}

I wish to express my thanks to Reviewers for their precious remarks and advice. 


\section{REFERENCES}

Arup U. (2006): A new taxonomy of the Caloplaca citrina group in the Nordic countries, except Iceland. Lichenologist 38, 1: 1-20. http://dx.doi. org/10.1017/S0024282905005402

Arup U., SANdler Berlin E. (2011): A taxonomic study of Melanelixia fuliginosa in Europe. Lichenologist 43: 89-97. http://dx.doi.org/10.1017/ S0024282910000678

BARKMAN J.J. (1969): The influence of air pollution on bryophytes and lichens, in air pollution. In: Proc. 1st Eur. Congr. Influence of Air Pollution on Plants and Animals. Wageningen, 1968: 197209.

Blanco O., Crespo A., Divakar P.K., Esslinger T.L., Hawksworth D.L., Lumbsch H. T. (2004): Melanelixia and Melanohalea, two new genera segregated from Melanelia (Parmeliaceae) based on molecular and morphological data. Mycological Research 108, 8: 873-884. http://dx.doi.org/10.1017/ S0953756204000723

Bystrek J., Kolanko K. (2000): Porosty (Lichenes) Puszczy Knyszyńskiej. Zakład Poligraficzny BiS, Lublin.

Cieśliński S. (2003 a): Atlas rozmieszczenia porostów (Lichenes) w Polsce Północno-Wschodniej. Phytocoenosis (N.S.), Suppl. Cartographiae Geobotanicae 15 .

CIEśLIŃSKI S. (2003 b): The influence of forest management on lichens in the Kozienicka Forest (Central Poland). Acta Mycologica 38, 1/2: 123-135.

CIEŚLIŃSKI S. (2007): Stan bioty porostów w wybranych rezerwatach w Puszczy Kozienickiej. Parki Narodowe i Rezerwaty Przyrody 26, 3: 3-21.

Cieśliński S. (2008): Znaczenie ochrony rezerwatowej dla zachowania bioty porostów (Ascomycota lichenisati) w Puszczy Kozienickiej. Studia i Materiały Centrum Edukacji Przyrodniczo-Leśnej 10, 3(19): 99-109.

Cieśliński S., Czyżewska K., Fabiszewski J. (2006): Red list of the lichens in Poland. In: Z. Mirek, K. Zarzycki, W. Wojewoda, Z. Szeląg. W. Szafer (eds). Red list of plants and fungi in Poland. W: Czerwona lista porostów w Polsce. Czerwona lista roślin i grzybów Polski. Institute of Botany, Polish Academy of Sciences, Kraków: 71-90.

ĆWIKLIŃsKi E., GŁOWACKI Z. (2000): Atlas florystyczny doliny Bugu. In: J.B. Faliński, E. Ćwikliński, Z. Głowacki (eds). Atlas geobotaniczny Doliny Bugu. Part 1: Od Niemirowa do ujścia. Phytocoenosis (N.S.). Suppl., Cartographiae Geobotanicae 12: 73-299.

Fattynowicz W. (2003): The lichens lichenicolous and allied fungi of Poland. An annotated checklist. Krytyczna lista porostów i grzybów napo- rostowych Polski. W. Szafer Institute of Botany, Polish Academy of Sciences, Kraków.

Kondracki J. (1998): Geografia regionalna Polski. Wyd. Nauk. PWN, Warszawa.

LAUNDON J.R. (2010): Lecanora antiqua, a new saxicolous species from Great Britain, and the nomenclature and authorship of L. albescens, L. conferta and L. muralis. Lichenologist 42, 6: 631-635. http://dx.doi.org/10.1017/S0024282910000393

Marciniuk P. (2009): Szata roślinna śródpolnych siedlisk Podlaskiego Przełomu Bugu. Instytut Botaniki im. W. Szafera PAN, Kraków.

Orange A., James P.W., White F.J. (2001): Microchemical methods for the identification of lichens. British Lichen Society, London.

Przyroda Parku Krajobrazowego Podlaskiego Przełom Bugu. http://www.podlaskiprzelombugu.pl/ przyroda.html (21.03.2013).

RoZPORZĄDZENIE Ministra Środowiska z dnia 9 lipca 2004 r. w sprawie gatunków dziko występujących grzybów objętych ochroną. Dz.U. nr 168, poz. 1765.

Rzymowska Z. (2010): Plant communities of cultivated field sof the Podlaski Przełom Bugu mesoregion. Part 6. Communities of root crops on compact soils. Acta Agrobotanica 63, 1: 235-257. http://dx.doi.org/10.5586/aa.2010.026

RZYMOWSKa Z., SKRZYCZyŃSKa J. (2006 a): Plant communities of the cultivated fields of the Podlaski Przełom Bugu mesoregion. Part 2. Cereal communities. Acta Agrobotanica 59, 2: 377-391. http://dx.doi.org/10.5586/aa.2006.091

RZYMowsKa Z., SKRZYCZYŃSKa J. (2006 b): Plant communities of cultivated fields of the Podlaski Przełom Bugu mesoregion. Part 3. Stubble field communites on sandy soils. Acta Agrobotanica 59, 2: 393-419. http://dx.doi.org/10.5586/ aa.2006.092

RZYMOWSKa Z., SKRZYCZYŃSKa J. (2006 c): Plant communities of cultivated fields of the Podlaski Przełom Bugu mesoregion. Part 4. Stubble field communites of compact soils. Acta Agrobotanica 59, 2: 421-440. http://dx.doi.org/10.5586/ aa.2006.093

SkrZYCZYŃSKA J., STACHOWicz P. (2007): Flora of fallow lands of the Podlaski Przełom Bugu mesoregion. Acta Agrobotanica 60, 1: 175-190. http://dx.doi. org/10.5586/aa.2007.021

SoкоŁowski A.W. (1991): Przyrodnicze obiekty chronione województwa białostockiego. Wojewódzki Konserwator Przyrody, Białystok.

Wierzba M., Sikorki P., Krechowski J., Piórek K. (2010): Naturalne i półnaturalne elementy szaty roślinnej Podlaskiego Przełomu Bugu. In: A. Obidziński (ed.). Z Mazowsza na Polesie i Wileńszczyznę. Zróżnicowanie i ochrona szaty roślinnej pogranicza Europy Środkowej i Północno-Wschodniej. Monografia sesji terenowych 
LV Zjazdu Polskiego Towarzystwa Botanicznego Planta in vivo, in vitro et in silico. Warszawa, 6-12 września 2010. Polskie Towarzystwo Botaniczne - Zarząd Główny, Warszawa: 173-193.

ZalewsKa A., Fattynowicz W., Krzysztofiak A., Krzysztofiak L., PicińsKa-FaetYnowicz J. (2004):
Lichens of Suwalski Landscape Park. In: A. Zalewska, W. Fałtynowicz (eds). Lichens of the protected areas in the Euroregion Niemen. Helios, Suwałki: 5-50. 